\title{
Sectoral ICORs of South Sulawesi Province
}

\section{Muhammad Agung Ady Mangilep${ }^{1}$, Fitriwati Djaman², Retno Susanti ${ }^{3}$ and Adelia Undangsari Ady Mangilep ${ }^{4}$}

\author{
${ }^{1}$ Hasanuddin University, Indonesia, e-mail: agungam@fe.unhas.ac.id \\ ${ }^{2}$ Hasanuddin University, Indonesia \\ ${ }^{3}$ Hasanuddin University, Indonesia \\ ${ }^{4}$ Hasanuddin University, Indonesia
}

\begin{abstract}
This research is aimed to find out sectoral ICORs of South Sulawesi Province. This research uses quantitative data obtained from a series of Indonesian government's publications. The ICOR method is used to calculate an ICOR coefficient. This research found that the ICOR of South Sulawesi Province is low. Sectoral ICORs are low, except the power, gas, water and services sector. Keywords: ICOR, investment, economic planning
\end{abstract}

\section{Introduction}

South Sulawesi Province is one of Indonesia's regions, which plays an important role as eastern gate of Indonesia and has become the center of economic activities in eastern Indonesia. Furthermore, South Sulawesi is one of the leading provinces in the eastern of Indonesia.

South Sulawesi Province has been trying to enhance economic development by increasing GDRP. With a GDRP per capita at just one-seventh of East Kalimantan Province and about 0.65 percent of the GDP of Indonesia, South Sulawesi Province needs a great effort to catch up. Investment is one of the most effective ways to increase capital formation. For that, it needs proper investment planning. ICOR calculation as an indicator to the needs of investment to each economic sector in South Sulawesi Province will affect the accuracy of investment planning in South Sulawesi Province. This paper is aimed to find out sectoral ICORs of South Sulawesi Province.

Concept of Capital Output Ratio or Coefficient of Capital is an instrument for economic analysis. Seth (1971) points out capital that needed to increase revenue can be calculated by the capital output ratio. Rosen (1959) states simply that the capital-output ratio can be defined as a relationship between investment in an economy or a particular industry at a particular time period with output in that economy or industry in the same period. Jhingan (1983) points out capital that is needed to increase output is calculated by a capital-output ratio. Agrawal and Lal (1977) states that a capital-output ratio is needed for a developing country's planning which has been started to use in developed countries. Capital Output Ratio can be divided into two forms. Jhingan (1983) distinguishes between Average Capital Output Ratio and Marginal Capital Output Ratio where marginal means incremental. Average Capital Output Ratio (ACOR) shows the relationship between the existing capital stock and output flows smoothly produced. Incremental Capital Output Ratio (ICOR) shows the relationship between the amount of increase in output/income $(\Delta \mathrm{Y})$ resulting from a particular increase in the capital stock $(\Delta \mathrm{K})$ which can be described as $\Delta \mathrm{K} / \Delta \mathrm{Y}$. In other words, according to Tinbergen, ACOR show everything that has been invested in the past and in the overall revenue, while ICOR shows everything that is currently added to the capital or income. The former is a static concept, while the latter is a dynamic concept. Therefore, the term Capital Output Ratio as used in economics is concerned with the ICOR. This ratio is usually moving between 3 and 4 depending on a period. Because it has a time dimension, in communist countries he referred it to "replacement period".

Use of Capital Output Ratio as a tool to estimate the capital needed in underdeveloped countries faces a number of limitations, including:

a. Kurihara (in Jhingan, 1983) stated that calculating the Capital Output Ratio accurately could only be made in the framework of a real development program and technological data on costs and 
output. But such data are not easily available in the underdeveloped economy. Tangible development programs is hampered by the lack of capital equipment, labor and entrepreneurship skills, changes in demand, prices and climatic conditions that adversely affect the output.

b. Capital output ratio may not remain constant throughout the period of the plan. It changes with the progresses of development from year to year. Consequently, there is a large difference between the ratio and the ratio of factual expectations. For example, India's First Five-Year Plan assumes that Marginal Capital Output Ratio 3:1, but in fact 1.8:1.

c. Use of Capital Output Ratio as a tool of economic planning is limited by the degree of underutilization or inefficient use of resources in an underdeveloped economy. Because of it, it is extremely difficult to calculate Capital Output Ratio accurately.

d. Capital Output Ratio is a tool to estimate the total capital needs of an economy but cannot be used to set priorities among the various sectors or projects in the economy.

e. Capital Output Ratio cannot explain to us about the human capital investment needed to achieve a certain growth rate. Investment in human capital is important for economic growth just as physical capital.

f. There are practical difficulties in calculating the Capital Output Ratio. It is usually assumed that there is no change in the technology. However, there is a possibility that a technological innovation increases output with the same amount of capital, or the same output can be obtained with less capital, so that it would change the Capital Output Ratio.

g. Capital Output Ratio concept is based on the implicit assumption that if the capital increase, supply of factors used with it also increases. But in an underdeveloped economy, supporting factors like power engineering, entrepreneurship, natural resources, transportation and so on are all very rare. Therefore, the concept cannot be applied in the context of underdeveloped economies.

h. Difficulties arise in measuring capital and output. Myrdal (in Jhingan, 1983) reveals the following. First, in the underdeveloped economy of state investment and private investment are grouped into one capital input. Estimating capital investment as it is may not be appropriate because the ratio of these investments may change. Second, various restrictions and control directly inhibits price to adjust demand and supply. So, estimating it requires a calculation of shadow prices. Third, exclusivity, heterogeneity, complementarily and indivisibility of capital in the Southeast Asia does not allow such grouping. Fourth, if there are several items on each part of the Capital Output Ratio, and if things are not equally change proportionally, we are faced with the problem of index numbers, including infinity caused by changes the price in the planning period and by a variety of income distribution. Furthermore, anything that changes the relative price of capital goods and consumer goods in general, whether from demand side or the supply side, will change the Capital Output Ratio, even without changing physical capital, physical or technological output. Especially changes in real wages, interest rates and import prices will change the Capital Output Ratio, though the composition of capital and techniques has not changed.

i. During the depression, all of the increase in capital will be followed by a decrease in output and in this situation the past Capital Output Ratio became a meaningless concept.

j. Above all, the use of Capital Output Ratio as a technique for testing the development plans of a country does not take us too far backwards. Overall Capital Output Ratio is the average sectoral ratio. National output is the sum of a variety of goods and services produced by a variety of economic sectors, each of which has a different Capital Output Ratio. Sectoral capital output ratio is high for some sectors such as housing, transportation, communication, irrigation and power projects, and low for agricultural services and consumer goods industries. But it is difficult to calculate the sectoral capital output ratio due to a lack of statistical data. Conceptual difficulties also arise in the case of certain items such as fertilizer, which can be placed in agriculture or 
chemical industry sector. Overall, Capital Output Ratio reflecting sectoral ratios, is not a precise estimate to test the consistency of the development plan.

As a conclusion, regardless of the theoretical and practical limitations above, Capital Output Ratio is widely used as a planning tool. Predictions is weak, but the results are more meaningful in the longrun rather than short-run. Analytically, it is useful as a tool to make a rough and fast calculation easy. However, Kindleberger (in Jhingan, 1983) argued, in an imperfect situation, it almost resemble to a planning tool.

Capital output ratio does have its limitations. However, the Capital Output Ratio also has significance in planning. Jhingan (1983) reveals that the capital output ratio is an important and useful concept of economic planning in underdeveloped countries, especially when consistency was checked between national growth targets and additional capital from current foreign investment. In order to estimate the financial needs, it is necessary to estimate the growth in the volume of investment required to achieve a certain output target. Thus, Capital Output Ratio can be used to determine the rate of growth of an economy. Harrod-Domar's growth pattern (in Jhingan, 1983) is based on this concept.

In formulating a plan, ICOR is necessary for the purpose of calculating the rate of economic growth. Suppose we want to increase national output by 10 and assume his ICOR of 2 . In this case a necessary addition to the stock of capital needed for new investment will be $(10 \times 2)=20$. Suppose the level of national output in progress is 1,000 and the savings rate is 0.04 , so that domestic savings would be 40. Further domestic savings can be invested for the purpose of increasing national output. Based on ICOR 2, the amount of savings or investment 20 would increase national output to 10 . This gives the rate of growth of national income by 2 percent per year. We can also calculate the rate of growth of output (revenue) by dividing the ratio of national savings with ICOR, example: $0.04 / 2=0.02$ or 2.0 percent.

In addition, to calculate the Capital Output Ratio, essential problem is that the investment flow from foreign aid is so great. Because the ratio of domestic savings to income in underdeveloped countries is low, achieving a high rate of growth required a large foreign aid. With this regard conventional Capital Output Ratio becomes 3 to 4. So the concept of capital output ratio is a useful tool to highlight the importance of capital in development planning, and to test the consistency of the desired growth rate and existing resources in underdeveloped countries.

\section{Research Methodology}

The ICOR calculation is:

$$
\mathrm{ICOR}=\frac{I}{\Delta Y}
$$

My research uses a formula as follows:

$$
\mathrm{ICOR}=\frac{G D R I}{\Delta G D R P}
$$

Description:

ICOR $=$ Incremental Capital Output Ratio

GDRI $=$ Gross Domestic Regional Investment

$\Delta$ GDRP $=$ a change of Gross Domestic Regional Product

ICOR has a range of 2 to 7 . If the results of ICOR calculations show greater than seven, the ICOR is high. Conversely, if the results of ICOR calculations show less than or equal to two, the ICOR is low. If the calculation results ICOR is high, then the null hypothesis is accepted. Conversely, if the calculation of ICOR is low, the null hypothesis is rejected.

This research used secondary data on the value of investments and the value of GDP of South Sulawesi from 1993 to 2002. Data is collected from publications by the Central Bureau of Statistics, the Bank of Indonesia and the Government of South Sulawesi Province. Those publications are The Economic and Regional Financial Development in South Sulawesi on 2nd Quarter of 2002 (Bank 
Indonesia, 2002), A Progress of Economy, Banking, and Payment System in South Sulawesi Province (Bank Indonesia, 2001), Regional Economic and Financial Statistics of South Sulawesi Province on May 2002 (Bank Indonesia, 2002), GDRPs of South Sulawesi Province in 1993-1996 (Biro Pusat Statistik, 1997), The GDRP of South Sulawesi Province in 2002 (Biro Pusat Statistik, 2002), ICORs of South Sulawesi in 1992-1996 (Biro Pusat Statistik, 1997), The South Sulawesi in Numbers in 2001 (Biro Pusat Statistik, 2002), The South Sulawesi in Numbers in 2002 (Biro Pusat Statistik, 2003), Indonesian Provincial GDRPs by Economic Sectors in 1998-2001 (Biro Pusat Statistik, 2002), The Investment Map of South Sulawesi Province (Pemda Sulsel. 1999),

\section{Result and Discussion}

ICOR calculations are performed on each sector of the economy. Classification of economic sectors in GDP are divided into nine sectors:

a. agriculture

b. mining and quarrying

c. manufacturing

d. power, gas and water supply

e. construction

f. trade, hotel and restaurant

g. transportation and communication

h. finance, rent and business services

i. services

Meanwhile, the classification of economic sectors by investment, both domestic and foreign simply divide into eight sectors, where the power sector is coupled with the financial sector, rent and business services and the services sector since to the investment value of each sector are very small. Therefore sectoral division is adjusted to the sectoral distribution of investment data, both domestic and foreign, as following:

a. agriculture

b. mining and quarrying

c. manufacturing

d. power, gas, water supply and services

e. construction

f. trade, hotel and restaurant

g. transportation sector and communication

$\mathrm{h}$. finance, rent and business services

ICOR calculation results of the South Sulawesi Province 1993-2002 showed fluctuations, with the highest ICOR coefficient of 3.28 in 1997 and the lowest coefficient of -12.56 in the next year. ICOR coefficient has a range of 2 to 7 (Nafziger, 1997), and ICOR is getting better when it gets closer to 2 and vice versa, but for lower than 7 ICOR is still good. In general, the coefficient of ICOR of the South Sulawesi Province from 1993 to 2002 was under 2, but in 1994, 1997 and 1999 were above 2. There was no ICOR coefficient which exceeds 7. Accumulated ICOR coefficient of the South Sulawesi Province was 2.86. It indicated that the ICOR of the South Sulawesi Province, which is accumulated from 1993 to 2002, was low, and it was very good. This value also implied that increasing the level of investment by 2.86 percent per year could increase growth by 1 percent.

Negative values of ICOR can occur if the output at any given time is smaller than the previous year. It occurred in South Sulawesi in 1998 where the ICOR coefficient was at -12.56. This occurred when the GDRP of the South Sulawesi Province in 1998 amounted to Rp 9.36 trillion, lower than the GDRP of the South Sulawesi Province in 1997 that had amounted to Rp 9.89 trillion, a drop of 5.33 percent. One cause of the decline in GDRP is a decline in exports from \$ 535.175 million in 1997 to \$528.163 million in 1998. The sharp depreciation of the Rupiah Rp 4,650.00 per dollar to Rp 10,700.00 widened the gap in values of exports. 
In the agricultural sector, ICOR coefficient for the period of 1993-2002 generally showed a steady movement as shown in Figure 4.4. A fluctuation was a sharp increase in 1998 to reach 299.27, a value that has never happened before and after that year. ICOR coefficient formed for the period of 19932002 was low even under 2. ICOR coefficient greater than 2 only occurred in 1998 and 1999 amounted to 299.27 and 3.29. In 1998, ICOR coefficient even far beyond 7, a condition that was very bad and very inefficient.

A negative ICOR coefficient also occurred in the agricultural sector that was equal to -1.19 in 1997 . For the period of 1993-2002, ICOR coefficient was averaged to 1.65, it means that the agricultural sector from the year 1993 to 2002 are very efficient, but on the contrary, the investment realized was very low.

In the mining and quarrying sector, ICOR coefficient for the period of 1993-2002 generally showed a fluctuating movement as shown in Figure 4.5. A fluctuation was happened when ICOR reached 2.8 in 1996, while in previous years was zero. Then ICOR coefficient was negative and equal to -2.63 in 1997, and subsequently in 1998 increased to 0.07 and then back to zero.

ICOR coefficient of the mining and quarrying sector, which was formed from the year 1993-2002, was low, even under 2. ICOR coefficient greater than 2 only occurred in 1996 at 2.8. The sector of mining and quarrying, conversely to the agricultural sector, did not have the ICOR coefficient that exceeded 7.

A negative ICOR coefficient also occurred in the mining and quarrying sector in 1997 at -2.63 , and the same thing happened in the agricultural sector in the same year. For the period of 1993-2002, ICOR coefficient was averaged to 0.55 . Because this value was under 2 , it can be interpreted that the mining and quarrying sector from the year 1993 to 2002 were very efficient, but the investment actually realized was very low.

In the manufacturing sector, ICOR coefficient for the period of 1993-2002 generally showed highly fluctuating movement as shown in Figure 4.6. A fluctuation was a sharp increase to 12.04 in 1994; and declined to -4.77 in 1998. ICOR coefficient then increased again in 1999, reaching 6.76, and subsequent fluctuations occurred again in 2002 with an increase of 8.85.

ICOR coefficients of the manufacturing sector in years 1993-2002 are varied. ICOR coefficient greater than 2 occurred in 1994 at 12.04; in 1996 at 3.68; in 1997 at 2.16; in 1999 at 6.76, and in 2002 at 8.85. Unlike the mining and quarrying sector, but similar to the agricultural sector, the manufacturing sector had ICOR coefficient that exceeded 7, in 1994, which was equal to 12.04, and in 2002, which was 8.85, a condition which was not good.

A negative ICOR coefficient also occurred in the manufacturing sector at -4.77 in 1998 . For the period of 1993-2002, ICOR coefficient was averaged to 4.52, and because this value was above 2, it could be interpreted that the conditions of the manufacturing sector from 1993 to 2002 was good.

In the power, gas, water supply and services, ICOR coefficient for the period of 1993-2002 generally showed a steady movement as shown in Figure 4.7. A fluctuation was increased to 8.03 in 1997. Then ICOR coefficient turned out even negative coefficient at -74.16 in 1998, and then increased again until 2.66 in 2002.

ICOR coefficients of power, gas, water supply and services in period 1993-2002 were more than 2 in 1997 and 2002 at 8.03 and 2.66. Similar to agriculture, power, gas, water supply and services had ICOR coefficient that exceeded 7 in 1997 at 8.03, a condition which was not good.

A negative ICOR coefficient also occurred in the power, gas, water supply and services at -74.63 in 1998, and the same thing happened in several other sectors (in the same year, ICOR coefficient of industry also experienced a negative value). For the period of 1993-2002, ICOR coefficient was 10.35 an average. Therefore this value is higher than 7, so it can be interpreted that the condition of power, gas, water supply and services from year 1993 to 2002 was not good and inefficient.

In the construction sector, ICOR coefficient for the period of 1993-2002 generally showed a steady movement as shown in Figure 4.8. Fluctuations was happened where ICOR coefficient reached 6.37 in 1997, then dropped to zero in 1998 and thereafter. 
ICOR coefficients of the construction sector in period 1993-2002 were more than 2 only in 1997 at 6.37. The construction sector was conversely to the agricultural sector, it did not have an ICOR coefficient that exceeded 7 , so it was a good condition.

A negative ICOR coefficient was not present in the construction sector. For the period of 1993-2002, ICOR coefficient was averaged to 4.04. Because this value is below 7 so it can be interpreted that the condition of the construction sector in this period was good and efficient.

However, many zero values showed that the construction sector has very low investment rate. For the period of research, investment only occurred in 1996 and 1997.

In the trade, hotels and restaurants sector, ICOR coefficient for the period of 1993-2002 generally showed a fluctuating movement as shown in Figure 4.9. Fluctuations occurred where there was an increase in 1994 at 0.36; continued to increase in 1995 at 0.45; then fell down to 0.31 in 1996; but in 1997 it increased to 1.57 .

ICOR coefficients of trade, hotels and restaurants for the period of 1993-2002 were low even under 2. There was no ICOR coefficient greater than 2; and the highest ICOR coefficient was in 1997 at only 1.57. Thus, conversely to the agricultural sector, trade, hotels and restaurants do not have the ICOR coefficient that exceeded 7.

A negative ICOR coefficient was not found in the trade, hotels and restaurants, the same thing happened in the construction sector. For the period of 1993-2002, ICOR coefficient was averaged to 0.31 . Because this value is under 2, it can be interpreted that the trade, hotel and restaurant sector from 1993 to 2002 was very efficient, but the realized investment is very low.

Many zero values show that investment in the trade, hotel and restaurant sector was very low. For the period of research, the investment occurred only in a few years.

In the transportation and communication sector, ICOR coefficient for the period of 1993-2002 generally showed highly fluctuating movement as shown in Figure 4.10. Fluctuations was happened from 1993 to 1994 at 0.17 ; and in 1995 at 0.39 ; increased substantially to 1.74 in 1996 and then fell to 0.54 in 1997 before rising sharply to reach 3.96 in the following year. ICOR coefficient decreased again in 1999 to reach zero which continued until 2001 and then increased slightly in 2002 at 0.32 .

ICOR coefficients of transportation sector and communications sector, for the period of 1993-2002 were varied. However mostly ICOR coefficients in this sector were smaller than 2 . ICOR coefficient which was more than 2 only occurred in 1998 at 3.96 which was also the highest coefficient for the period of this research. It was the same as the mining and quarrying sector, but conversely to the agricultural sector, transportation sector and communications sectors that have ICOR coefficient more than 7.

A negative ICOR coefficient was not contained in the transportation sector and communications sector. For the period of 1993-2002, ICOR coefficient was 0.42 an average, therefore this value is under 2 so that it can be interpreted that the condition of transportation sector and communications sector in this period was efficient.

In the financial, rent, and services company sector, ICOR coefficient for the period of 1993-2002 generally showed a steady movement as shown in figure 4.11. Fluctuations occurred in 1993 of 2.67 which was then followed by a decline to zero in 1994; then an increased to 0.07 in 1995; fell to 0.02 in 1996; but then back to zero in 1997 and thereafter.

ICOR coefficients of financial, rent, and services company sector for the period of 1993-2002 were low even under 2. ICOR coefficient was more than 2 in 1993 at 2.67; and it was the highest in this sector. Thus, conversely to the agricultural sector, finance, rent, and service companies' sector did not have ICOR coefficient that exceeded 7.

A negative ICOR coefficient is not contained in the financial, rent, and services company sector, and the same thing happened in the construction sector in the same period of research. For the period of 1993-2002, ICOR coefficient was averaged to 1.04. Because this value was under 2, it can be interpreted that the financial, rent, and services company sector for the period of 1993-2002 was very efficient, but the realized investment is very low. 
For the period of 1993-2002, ICOR coefficients of entire economic sectors of the South Sulawesi Province were varied. On average, the highest ICOR coefficient was in the power, gas, water supply and services sector at 10.35. Meanwhile, the lowest coefficient of ICOR was in the trade, hotel and restaurant sector that is equal to 0.31 . There were some sectors that have coefficients more than 2 , like the manufacturing sector at 4.52; power, gas, water supply and services sector at 10.35 , and the construction sector at 4.04 .

We can also see that for the period of 1993-2002, there was only one sector of economy in South Sulawesi Province which has ICOR coefficient that exceeds 7, and it was on power, gas, water supply and services at 10.35 . Thus, this sector was very inefficient.

ICORs of economic sectors in South Sulawesi Province which classified as good were those of the manufacturing sector and the construction sector. Both sectors showed a good and efficient condition. In all sectors of the economy of the South Sulawesi Province, ICORs showed that there were no negative coefficients, so that for the period of 1993 to 2002 could be seen that the economy of the South Sulawesi Province had grown increased in every sector.

\section{Conclusion}

The ICOR of South Sulawesi Province in the period of 1993-2002 is low. By sectors, the ICOR of the agriculture sector is low, as well as the mining and quarrying sector, the manufacturing sector, the construction sector, the trade, hotel and restaurant sector, the transport and communications sector, and the finance, leasing and corporate services sector. The only one sectoral that has a high ICOR, is the power, gas, water and services sector.

\section{References}

Agrawal, A. N., Lal K. 1980. Economic Planning, Principles, Techniques and Practice. 2nd Ed., Vikas Publishing House PVT LTD, New Delhi.

Bank Indonesia.2002. Kajian Perkembangan Ekonomi dan Keuangan Daerah Sulsel Triwulan 22002. Makassar.

Bank Indonesia.2001. Perkembangan Ekonomi Perbankan dan Sistem Pembayaran Propinsi Sulsel dan Prospeknya. Makassar.

Bank Indonesia.2002. Statistik Ekonomi-Keuangan Daerah Sulsel Mei-2002. Makassar.

Biro Pusat Statistik.1997. PDRB Sulsel 1993-1996. Makassar.

Biro Pusat Statistik.1997. ICOR Sulsel 1992-1996. Makassar.

Biro Pusat Statistik.2003. PDRB Sulsel Tahun 2002. Makassar.

Biro Pusat Statistik.2002. Sulsel dalam Angka 2001. Makassar.

Biro Pusat Statistik.2003. Sulsel dalam Angka 2002. Makassar.

Biro Pusat Statistik.2002. PDRB Propinsi-propinsi di Indonesia menurut Lapangan Usaha 19982001.Jakarta.

Jhingan, M. L. 1983. Ekonomi Pembangunan dan Perencanaan. Raja Grafindo, Jakarta.

Pemda Sulsel. 1999. Peta Investasi Daerah Propinsi Sulawesi Selatan. Pemda Sulsel, Makassar. 